\title{
Multiple low-dose streptozotocin-induced diabetes in the mouse: further evidence for involvement of an anti-B cell cytotoxic cellular auto-immune response
}

\author{
R.C. McEvoy, ${ }^{1,2}$ N.M. Thomas, ${ }^{2}$ C. Hellerström, ${ }^{4}$ F. Ginsberg-Fellner ${ }^{1}$ and T. M. Moran ${ }^{1,3}$ \\ Departments of ${ }^{1}$ Pediatrics, ${ }^{2}$ Anatomy and ${ }^{3}$ Microbiology, Mount Sinai School of Medicine of the City University of New York, New York, \\ USA and ${ }^{4}$ Department of Medical Cell Biology, Uppsala University, Uppsala, Sweden
}

\begin{abstract}
Summary. Anti-B cell auto-immunity may play a role in the pathogenesis of diabetes in mice resulting from multiple subdiabetogenic doses of the pancreatic B cell toxin, streptozotocin. In the present study we have investigated the cytotoxic anti-B cell response in these mice. A major role for B lymphocytes, macrophages, or their products in the cytotoxic response originally detected in vitro was eliminated by passing splenocytes from the mice treated with multiple subdiabetogenic doses of streptozotocin over a nylon wool column. The removal of the adherent cells enhanced the cytotoxicity against a rat insulinoma cell line in vitro by that expected due to enrichment of T-lymphocytes by approximately twofold. The induction of diabetes after multiple subdiabetogenic doses of streptozotocin is strain dependent. Mice of five strains were immunized with rat insulinoma cells, but only splenocytes from the two strains susceptible to multiple subdiabetogenic doses of streptozotocin demonstrated a significant cytotoxic response against the rat insulinoma cells in vitro. Mice pre-immunized with either the rat insulinoma cells or with syngeneic islets labelled in vitro with the hapten trinitrophenol developed hyperglycaemia more rapidly than
\end{abstract}

control mice after multiple subdiabetogenic doses of streptozotocin. In the latter experiment the control mice immunized with complete Freund's adjuvant alone also became hyperglycaemic after a modified multiple subdiabetogenic dose of streptozotocin that did not cause diabetes in non-immunized mice. In mice pre-treated with either adjuvant or cyclophosphamide and then given a modified multiple subdiabetogenic dose of streptozotocin $(35 \mathrm{mg} / \mathrm{kg} \times 5$ rather than $40 \mathrm{mg}$ / $\mathrm{kg}$ ) the degree of hyperglycaemia was reduced and there was no protective effect of cyclophosphamide. However, the mice pre-treated with adjuvant again developed hyperglycaemia more rapidly and to a much higher level than did the mice given multiple subdiabetogenic doses of streptozotocin only. These additional data further support the hypothesis that Bcell destruction after multiple subdiabetogenic doses of streptozotocin results from triggering of an immune response against these insulin-producing cells.

Key words: Insulin-dependent diabetes, cellular immunity, mouse, streptozotocin, auto-immunity.
The involvement of the immune system in the pathogenesis of diabetes induced in mice by multiple subdiabetogenic doses of streptozotocin (MSZ) [1, 2] has been somewhat controversial. However, substantial evidence has been obtained over the last decade to support the hypothesis that this model of diabetes has a significant auto-immune component. Anti-mouse lymphocyte serum partially [2] or completely [3] prevented the onset of diabetes following MSZ. Several reports have indicated that athymic mice are resistant to MSZ diabetes [4-6], as are mice made immunodeficient by irradiation [7-10]. In both cases susceptibility could be restored by replacement of T-lymphocytes [8, 10] but not by preparations enriched in B lymphocytes [10]. Susceptibility to MSZ diabetes varies between different strains of mice, and seems to be at least partially linked to genes of the major histocompatibility com- plex, H-2, in mice [11-15]. Recently, transfer of activated lymphocytes from MSZ diabetic mice produced diabetes in the recipients after a single dose of streptozotocin (SZ) [16]. Activation of lymphocytes by concanavalin-A was required to obtain successful transfer in these mice as well as transfer of diabetes by lymphocytes from the $\mathrm{BB} / \mathrm{W}$ rat [17].

Although cyclosporin treatment prevented spontaneous diabetes in $\mathrm{BB}$ rats $[18,19]$, administration of this drug enhanced the diabetogenic effects of MSZ [20]. The dose of cyclosporin used in this latter study was relatively high, and blood levels were not measured. This is of concern since cyclosporin has been shown to directly inhibit insulin biosynthesis [21].

A report in 1981 described an 80-90\% reduction in pancreatic insulin, B-cell volume and glucose-stimulated insulin release on day 5 after the beginning of 
MSZ [22], but a more recent study could detect no reduction in B-cell granulation or volume density until days 15 and 18, respectively, after MSZ [23]. Both nicotinamide [24] and free radical scavengers [25] prevent diabetes induced by a single high dose of SZ, presumably by reducing direct toxicity at the level of the Bcell. However, neither of these agents prevents MSZ diabetes [26, 27], suggesting that direct cytotoxicity of $\mathrm{SZ}$ on the $\mathrm{B}$ cell is not the sole mechanism producing hyperglycaemia after MSZ.

We have previously reported that splenocytes from MSZ mice are cytotoxic against a rat B-cell line in vitro [28]. The cytotoxicity peaked on day 10-12 after MSZ, and was associated with the beginning of insulitis. It was dose-dependent, B-cell specific, and could be enhanced in vitro by culture of lymphocytes in the presence of the rat B-cells and Interleukin-2. Similar cytotoxicity has recently been reported by lymphocytes from BB rats using the same rat B-cell line as the target [29]. The current concept of cell-mediated immune response postulates that helper and cytotoxic T-lymphocytes can respond to their specific antigens only when these are presented in the context of self major histocompatibility complex (MHC) antigens (Class II for helper cells, Class I for cytotoxic cells) [30, 31]. Since syngeneic mouse B-cell lines are not yet available to provide sufficient numbers of cells for studies in vitro, we have continued to investigate the role of auto-immunity against the B cell after MSZ by experiments conducted largely in vivo.

\section{Materials and methods}

\section{Mice}

Young male mice $(20-25 \mathrm{~g})$ were used in all experiments. Fl hybrid $\mathrm{C} 3 \mathrm{D} 2$ mice (male DBA/2J $\times$ female $\mathrm{C} 3 \mathrm{H} / \mathrm{Tif}$ ) were purchased from Gl. Bomholtgaard (Ry, Denmark). C57BL/6J, DBA/2N, C3H/ $\mathrm{CN}$, and $\mathrm{A} / \mathrm{J} \mathrm{Cr}$ mice were obtained from the Animal Genetics and Production Branch, National Cancer Institute (Bethesda, Md, USA).

\section{Induction of diabetes}

One intraperitoneal injection of SZ (Sigma Chemical Company, St. Louis, Mo, USA, Lot 83F-0085) was given daily for 5 days ( $40 \mathrm{mg} / \mathrm{kg}$ daily in $0.2 \mathrm{ml}$ citrate buffer, $\mathrm{pH} 4.5$ [2]). The day after the first dose was designated day 1 . In experiments after immunization with syngeneic islets, the mice received $40 \mathrm{mg} / \mathrm{kg}$ daily for only 3 days, since preliminary data indicated that this dose did not result in hyperglycaemia in naive C3D2Fl mice. Finally, in the experiments using adjuvant and cyclophosphamide, the dose of $\mathrm{SZ}$ was reduced to $35 \mathrm{mg} / \mathrm{kg}$, but was given for 5 days. Again, previously untreated $\mathrm{C} 3 \mathrm{D} 2 \mathrm{Fl}$ mice did not become diabetic after this modified MSZ regimen. Control mice, which were included in each experiment, received identical injections of citrate buffer only.

\section{Maintenance of rat insulinoma $(R I N)$ cells}

A high-insulin secreting subclone (NY, [32]) of a cloned rat insulinoma cell line (RIN 5F [33]) was generously provided by Dr. P. Rubinstein (Lindsley F.Kimball Research Institute, New York Blood
Center, USA). This rat insulinoma cell line was maintained in tissue culture in RPMI medium supplemented with fetal bovine serum (heat-inactivated, $10 \%)$, glutamine $(1 \mathrm{mmol} / 1)$, HEPES (N-2-hydroxyethyl-piperazine- $\mathrm{N}^{*}$-ethanesulfonic acid, $10 \mathrm{mmol} / \mathrm{l}$ ), penicillin $(100 \mathrm{U} / \mathrm{ml})$, and streptomycin $(100 \mu \mathrm{g} / \mathrm{ml})$. This medium will hereafter be designated complete medium. RIN cells were passaged by detachment of the cells from the culture dish with trypsin-EDTA in calcium-magnesium free Earle's balanced salt solution. The single cell suspension was rinsed, counted in a microscope haemocytometer, and then either replated or used in the experiments. Culture media, sera and additives were purchased from Grand Island Biological Company (Grand Island, NY, USA). Sterile tissue cultureware was from Corning Glass Works (Corning, NY, USA).

\section{Splenocyte isolation}

Spleens were removed from the mice and the splenocytes isolated as previously decribed [28]. Approximately $1 \times 10^{8}$ nucleated splenocytes can be obtained from a single spleen with a viability of $98+\%$ as determined by trypan-blue dye exclusion. In some experiments $\mathrm{T}$ lymphocytes from C3D2Fl mice (days 10-12 after MSZ) were enriched by passing half of the splenocyte suspension through a column of nylon wool [34]. Nylon wool was taken from Leuco-Pak Leucocyte Filters (Travenol Laboratories, Morton Heights, Ill, USA). The yield of non-adherent cells averaged $35 \pm 5 \%$ in six experiments. Others have demonstrated an enrichment of $\mathrm{T}$ lymphocytes to $90-95 \%$ and removal of all but $1-2 \%$ of the B lymphocytes and macrophages by this technique [34]. The cytotoxicity of the $T$ cell enriched preparation was then compared to that of the original suspension of splenocytes. Splenocytes from control mice were always assayed in parallel.

\section{Cytotoxicity assay}

Cytotoxicity by the splenocytes or enriched $\mathrm{T}$ lymphocytes against the RIN cell targets was assayed as previously described [28], except that the assay was performed in round-bottomed wells of 96 well tissue culture dishes. $\mathrm{Na}_{2}{ }^{51} \mathrm{CrO}_{4}$ (Specific Activity: $200-500 \mu \mathrm{Ci} / \mu \mathrm{g}$ ) was purchased from New England Nuclear (Boston, Mass, USA). Maximum release was that present when the ${ }^{51} \mathrm{Cr}$-labelled RIN cells were added to wells containing an equal volume of $0.3 \%$ Triton $\mathrm{X}$ 100 in distilled water and averaged $12,169 \pm 1,112 \mathrm{cpm}$ in all of the experiments described here. Basal release was estimated by counts in the medium from wells in which the labelled RIN cells were incubated in complete medium only, and averaged $12.9 \pm 1.9 \%$ of the maximum in these experiments. The results are expressed as percent specific lysis [28]. Intra-assay variation among replicate samples averaged $1.1 \%$ of the counts. The results reported here represent meaned data obtained from at least 3 separate assays. In some experiments, other cell types were used as targets. These included rat lymphoblasts (day 3 after concanavalin-A [5 $\mu \mathrm{g} / \mathrm{ml}$ ] stimulation, YAC-1 cells, or $\mathrm{K} 562$ cells. These cells were used in the assay after ${ }^{51} \mathrm{Cr}$ labelling as described for the RIN cells [28].

\section{Strain variation in susceptibility to multiple subdiabetogenic doses of streptozotocin (MSZ)}

While strain differences in susceptibility to MSZ diabetes are welldocumented, the relative contributions of possible differences in the direct toxicity of SZ to the B cells versus stimulation of an anti-B cell auto-immune response have not been examined in different strains. To determine whether non-susceptible strains can mount a cytotoxic immune response against $B$ cell-related antigens, the immune response against RIN cells was estimated in five strains of mice, two susceptible to MSZ (C3D2Fl and C57BL/6J) and three non-susceptible (DBA/2N, C3H/CN, and A/J Cr). First, susceptibility to MSZ diabetes was confirmed in these strains of mice. Plasma glucose were determined three times weekly for up to 6 weeks; some of the mice 
Table 1. Enhancement of anti-RIN cell cytotoxicity by lymphocytes from MSZ mice after enrichment of T cells

\begin{tabular}{lcc}
\hline $\begin{array}{l}\text { Effector/ } \\
\text { target } \\
(\mathrm{E} / \mathrm{T}) \text { ratio }\end{array}$ & \multicolumn{2}{c}{ Specific lysis of RIN cells $(\%)$} \\
\cline { 2 - 3 } & Pre-nylon wool & Post-nylon wool \\
\hline 50 & $11.7 \pm 2.0$ & $18.5 \pm 1.2^{\mathrm{a}}$ \\
25 & $6.6 \pm 1.1$ & $12.0 \pm 0.9^{\mathrm{a}}$ \\
12.5 & $0.6 \pm 0.9^{\mathrm{b}}$ & $5.9 \pm 0.8^{\mathrm{a}}$ \\
\hline
\end{tabular}

Data are $\%$ specific lysis, mean $\pm \mathrm{SEM}, n=6$. Specific lysis was measured relative to that by control mouse splenocytes, which neither differed from basal nor increased after $\mathrm{T}$ cell enrichment.

Passage through nylon wool also increased cytotoxicity against YAC-1 cells (to $4.1 \pm 1.2 \%$ above basal, $\mathrm{E} / \mathrm{T}$ ratio $=50$ ), but there was no difference between control and MSZ splenocytes.

${ }^{a}$ Significantly above pre-nylon wool, $p<0.001$, ${ }^{b}$ not significantly above basal, $p>0.05$

Table 2. Strain variation in generation of a cytotoxic immune response after immunization with RIN cells

\begin{tabular}{lcrc}
\hline Strain & \multicolumn{3}{l}{ Effector/target ratio } \\
\cline { 2 - 4 } & \multicolumn{2}{l}{50} & \multicolumn{1}{c}{100} \\
\hline $\mathrm{C} 3 \mathrm{D} 2 \mathrm{Fl}$ & $4.8 \pm 1.1^{\mathrm{a}}$ & $9.7 \pm 0.9^{\mathrm{a}}$ & $15.9 \pm 1.6^{\mathrm{a}}$ \\
$\mathrm{C} 57 \mathrm{Bl} / 6 \mathrm{~J}$ & $5.1 \pm 1.2^{\mathrm{a}}$ & $8.5 \pm 0.7^{\mathrm{a}}$ & $9.6 \pm 2.5^{\mathrm{a}}$ \\
$\mathrm{DBA} / 2 \mathrm{~N}$ & $0.1 \pm 1.0$ & $-1.0 \pm 0.7$ & $-0.7 \pm 0.5$ \\
$\mathrm{C} 3 \mathrm{H} / \mathrm{CN}$ & $-0.4 \pm 1.2$ & $-0.4 \pm 0.5$ & $0.3 \pm 0.6$ \\
$\mathrm{~A} / \mathrm{J} \mathrm{Cr}$ & $-0.6 \pm 1.8$ & $0.1 \pm 0.7$ & $-1.2 \pm 2.1$ \\
\hline
\end{tabular}

Data are $\%$ specific lysis of RIN cells, mean $\pm \operatorname{SEM}(n=6)$. ${ }^{\text {a Signifi- }}$ cantly greater than basal, $p<0.001$.

After immunization with RIN cells, C3D2Fl and C57Bl/6J splenocytes also lyzed rat lymphoblasts $(1.3 \pm 0.7$ and $0.9 \pm 0.6 \%$ respectively)

were killed on day 12 after MSZ, and the pancreata examined histologically for the presence of insulitis. Naive mice of each strain were then immunized twice with RIN cells. Ten days after the second immunization, splenocytes were tested for cytotoxicity against RIN cells, and the pancreata were examined for the presence of insulitis.

\section{Immunization with RIN cells}

A single-cell suspension of RIN cells was prepared as above, rinsed twice in serum-free RPMI and $5 \times 10^{6}$ cells injected intraperitoneally in $0.2 \mathrm{ml}$. Two weeks later a second injection of $2 \times 10^{6}$ cells was given. After an additional 10 days, the immunized mice were either killed for determination of cytotoxicity against RIN cells in vitro or were given MSZ. Control mice were given identical intraperitoneal injections of medium only. Specific cytotoxicity against RIN cells was then reexamined 15 days after the first dose of SZ and compared to those of control mice (given MSZ only) or of immunized mice not given MSZ.

\section{Immunization with hapten-labelled syngeneic islets}

RIN cells are xenogeneic in these mice, and any stimulation of cytotoxicity or change in susceptibility to diabetes may have been due to non-specific stimulation of the immune response by immunization with these xenogeneic cells. To examine effects stimulated by B-cell antigens more specifically, islets were isolated from C3D2Fl mice using the collagenase technique [35]. Collagenase (from Clostridium histolyticum) was purchased from Boehringer Mannheim (Indianapolis, Ind, USA). Isolated islets were hand-picked with braking pipettes and labelled with the hapten, trinitrophenol (TNP), using a conventional technique [36]. After labelling, the islets were rinsed, emulsified in complete Freund's adjuvant and injected into both hind foot pads of C3D2Fl mice. Control mice received emulsified adjuvant only. Two weeks later the mice were given a second immunization with hapten-labelled syngeneic islets in incomplete Freund's adjuvant. Ten days after the second immunization the control and immunized mice were each divided into two groups, one to be given $\mathrm{SZ}(40 \mathrm{mg} / \mathrm{kg} \times 3$ days) and one citrate buffer only. Plasma glucose was determined twice weekly. Some of the mice were killed before SZ treatment and others 14 days after SZ. Pancreata of these mice were fixed in Bouin's solution, routinely embedded in paraffin, sectioned and stained with haematoxylin and eosin. The stained sections were examined for the presence of insulitis. The degree of insulitis was determined according to a grading system previously published [37] where $1+=$ normal islets, $2+=$ some infiltration by mononuclear cells, $3+=$ heavy infiltration into a large number of islets, and $4+=$ only a few small islets remaining.

\section{Other immunological modification}

The effects of non-specific stimulation of the immune system by injection of adjuvant or immunosuppression with cyclophosphamide were examined. C3D2Fl mice were given either adjuvant $(0.15 \mathrm{ml}$ intraperitoneally) or cyclophosphamide (Cytoxan, $3 \mathrm{mg}=120 \mathrm{mg} / \mathrm{kg}$ in $0.2 \mathrm{ml}$ intraperitoneally) 3 days before the first injection of MSZ. The dose of SZ was reduced to $35 \mathrm{mg} / \mathrm{kg}$ per day, but 5 daily injections were still given. Some of the pre-treated mice were given citrate buffer only as a control. Control mice received no pre-treatment and then were given either citrate buffer or MSZ.

\section{Determination of plasma glucose}

Blood was obtained from the retro-orbital sinus into heparinized capillary tubes. The concentration of glucose was determined immediately in fresh plasma by a glucose-oxidase method [38].

\section{Statistical analysis}

The statistical significance of the differences among the experimental groups was confirmed using Student's t-test in which differences were significant if $\mathrm{p}<0.05$.

\section{Results}

\section{Increased anti-B cell cytotoxicity after enrichment for $T$ lymphocytes}

As shown in Table 1, enrichment for $\mathrm{T}$ cells by passing splenocytes from mice given MSZ over a nylon wool column enhanced the specific lysis of RIN cells (as estimated by the ${ }^{51} \mathrm{Cr}$ release assay) by approximately 2 -fold at each of the effector/target $(\mathrm{E} / \mathrm{T})$ ratios tested. The specificity of the cytotoxicity detected by this assay was verified using rat lymphoblasts, YAC-1 cells and K562 cells as alternative targets. After passage over nylon wool, the non-adherent cells from control mice showed an increase in cytotoxicity above basal only against the YAC- 1 cells (to $4.1 \pm 1.2 \%$ above basa). There was no difference in the cytotoxicity against the YAC-1 cells between the splenocytes from the control and MSZ mice either before or after passage over the nylon wool. 
Strain differences in cytotoxicity after immunization with rat insulinoma $(R I N)$ cells

A preliminary study confirmed that only $\mathrm{C} 3 \mathrm{D} 2 \mathrm{Fl}$ and C57BL/6J mice exhibited elevations in plasma glucose after MSZ. Insulitis was present in all six mice examined from both of the susceptible strains ( 2 mice, Grade 2; 4 mice, Grade 3) on day 12 after MSZ. No insulitis was noted in sections from pancreata of any of the other strains. The differences among the mouse strains in cytolytic response after immunization with RIN cells are presented in Table 2 . The cytotoxicity by the C3D2Fl splenocytes was similar to that previously reported [28]. Of the other four strains, only the C57BL/6J splenocytes exhibited specific cytotoxicity in the ${ }^{51} \mathrm{Cr}$ release assay. Incubation of the radiolabelled RIN cells with splenocytes from the other three strains resulted in no increase in release above the basal ${ }^{51} \mathrm{Cr}$ release. No elevation in plasma glucose and no insulitis was noted in any of the mice immunized with RIN cells regardless of the strain. There was no detectable increase in cytotoxicity against either YAC-1 or K562 cells after immunization with RIN cells. Cytotoxicity against rat lymphoblasts was detected at an E/

Table 3. Effect of pre-immunization with RIN cells on plasma glucose concentration and cytotoxicity after a modified MSZ treatment

\begin{tabular}{lllll}
\hline Parameter & Group & Day 5 & Day 12 & Day 15 \\
\hline Plasma & Immunized only & $10.2 \pm 0.3$ & $10.5 \pm 0.2$ & $10.0 \pm 0.4$ \\
glucose & MSZ only & $10.3 \pm 0.4$ & $13.9 \pm 0.5$ & $18.9 \pm 1.2$ \\
(mmol/1) & Immunized/MSZ & $16.9 \pm 0.6^{\mathrm{a}}$ & $24.1 \pm 1.0^{\mathrm{a}}$ & $30.4 \pm 1.6^{\mathrm{a}}$ \\
Specific & Immunized only & - & - & $4.6 \pm 1.2$ \\
lysis & MSZ only & - & - & $7.3 \pm 1.8$ \\
$(\%)$ & Immunized/MSZ - & - & $13.0 \pm 2.5^{\mathrm{a}}$ \\
\hline
\end{tabular}

Data are mean $\pm \operatorname{SEM}(n=6)$. Specific lysis was determined at an effector/target ratio of 100 . ${ }^{a}$ Significantly greater than MSZ only, $p<0.005$
$\mathrm{T}$ ratio of $100: 1$ from both $\mathrm{C} 3 \mathrm{D} 2 \mathrm{Fl}(1.3 \pm 0.7 \%)$ and C57BL/6J $(0.9 \pm 0.6 \%)$ mice after the immunizations with the RIN cells. While these levels are significantly above basal $(p<0.01)$, they are far below those detected against RIN cell targets (Table 2).

\section{Immunization with RIN cells before multiple subdiabetogenic doses of streptozotocin (MSZ)}

As summarized in Table 3, the mice immunized with RIN cells prior to a modified MSZ treatment had a significantly greater rise in plasma glucose than the control mice $(p<0.001)$. Immunization alone did not affect plasma glucose concentration. On day 15 after MSZ the anti-B cell cytotoxicity, as measured in the ${ }^{51} \mathrm{Cr}$ release assay, was greater in the immunized MSZ mice than in either the immunized only or MSZ-only controls.

\section{Immunization with hapten-labelled syngeneic islets before $M S Z$}

C3D2Fl mice immunized with syngeneic islets labelled with the hapten, TNP, produced both antibodies which bound to RIN cell targets (data not presented) and a low level of cell-mediated cytotoxicity against the RIN cells $(\%$ lysis $=6.8 \%$ at an $\mathrm{E} / \mathrm{T}$ ratio of 100 as calculated from that of splenocytes from a control mouse immunized only with TNP which was not significantly different from basal release $p<0.05$ ). The changes in plasma glucose of mice immunized with syngeneic islets and then given a modified MSZ are summarized in Table 4. The mice immunized with syngeneic islets developed significant hyperglycaemia much more rapidly after the MSZ $(p<0.01)$, although the mice that received only the modified MSZ plus adjuvant as controls were significantly hyperglycaemic after week 7

Table 4. Effect of pre-immunization with syngeneic islets on hyperglycaemia induced by a modified MSZ treatment

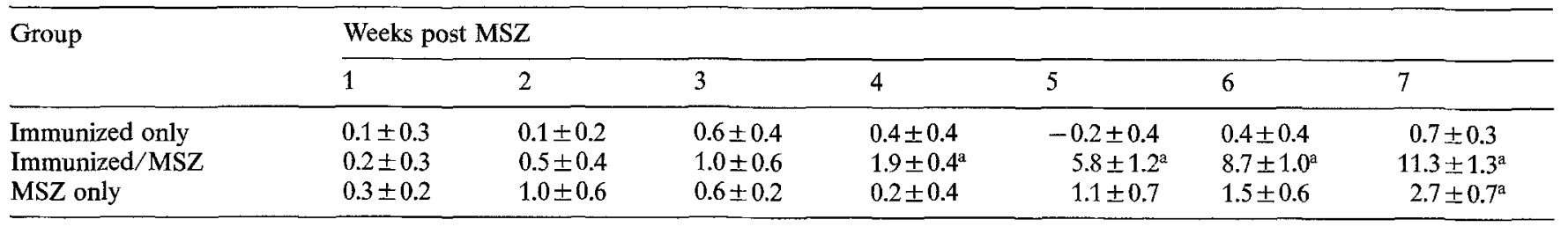

Data are plasma glucose above control mean, mmol $/ 1$, mean $\pm \operatorname{SEM}(n=6) ;$ Control plasma glucose $=8.5 \pm 0.3 \mathrm{mmol} / 1, n=60$. ${ }^{\text {a }} \mathrm{Significantly}$ greater than control, $p<0.01$

Table 5. Effect of pretreatment with complete adjuvant or cyclophosphamide on diabetes induced by a modified MSZ treatment

\begin{tabular}{lllllc}
\hline Group & \multicolumn{2}{l}{ Weeks post MSZ } & & & \\
\cline { 2 - 6 } & 1 & 2 & 3 & 3 & 5 \\
\hline MSZ only & $1.2 \pm 0.4$ & $1.4 \pm 0.4$ & $2.8 \pm 0.6^{\mathrm{a}}$ & $3.5 \pm 0.7^{\mathrm{a}}$ & $6.4 \pm 0.9^{\mathrm{a}}$ \\
Adjuvant & $0.6 \pm 0.2$ & $1.0 \pm 0.7$ & $4.6 \pm 0.8^{\mathrm{a}, \mathrm{b}}$ & $10.7 \pm 1.7^{\mathrm{a}, \mathrm{b}}$ & $10.9 \pm 1.2^{\mathrm{a}, \mathrm{b}}$ \\
Cytoxan & $1.6 \pm 0.7$ & $1.2 \pm 0.5$ & $2.4 \pm 1.0^{\mathrm{a}}$ & $4.1 \pm 0.8^{\mathrm{a}}$ & $5.0 \pm 1.2^{\mathrm{a}}$ \\
\hline
\end{tabular}

Data are plasma glucose above control, mmol/1, mean $\pm \operatorname{SEM}(n=6)$. Control mouse plasma glucose $8.8 \pm 0.3 \mathrm{mmol} / \mathrm{l}, n=30$. ${ }^{a}$ Significantly greater than control, $p<0.01$. ${ }^{\mathrm{b}}$ Significantly greater than MSZ only, $p<0.01$ 
$(p<0.01)$. Pancreata from immunized mice prior to the modified MSZ showed no insulitis. However, 14 days after the first dose of SZ many of the islets from the immunized mice were heavily infiltrated with monoculear cells (Grade 3). There was also very occasional mild insulitis in the non-immunized control mice given the modified MSZ (rare islets, Grade 2).

\section{Enhancement of MSZ Type I diabetes by immunological modification}

As shown in Table 5, the plasma glucose levels of the mice treated with the modified MSZ $(35 \mathrm{mg} / \mathrm{kg} \times 5)$ alone were significantly below those observed after the usual dose of MSZ (c.f. 2 weeks with Table 3, day 15, $p<0.01$ ). Indeed, this served to highlight the enhancement of the hyperglycaemia after immune stimulation by adjuvant. The mice given adjuvant before the modified MSZ had a significantly higher plasma glucose by day 18 after MSZ $(p<0.01)$ compared to those treated with the MSZ only. On the other hand, at this dose of MSZ cyclophosphamide treatment did not result in significantly higher plasma glucose levels when compared to C3D2Fl mice given modified MSZ alone. Incidently, the enhancement of hyperglycaemia in this experiment by pre-treatment with adjuvant may explain the mild hyperglycaemia in the non-immunized control mice in Table 4 . These mice had received adjuvant alone as a control for the immunization with syngeneic islets; the adjuvant given in the footpads may have had a similar effect to increase the plasma glucose after the modified MSZ.

\section{Discussion}

The results of these experiments offer additional evidence, albeit of an indirect nature, that diabetes after MSZ has an auto-immune component. Others have indicated that islet cell surface antibodies were detectable after MSZ [39], and we also have preliminary data confirming the presence of low titres of such antibodies in C3D2Fl mice after MSZ. In addition, Interleukin-I, a lymphokine released by macrophages, has recently been shown to be directly toxic to islet cells in vitro [40]. We therefore considered it relevant to exclude a contribution of these factors to the anti-B cell cytotoxicity we had previously reported [28]. The present observation that removal of nylon wool adherent cells, and thereby enrichment of the thymus-derived lymphocytes enhanced the specific lysis of the RIN cells, suggests that neither B lymphocytes, macrophages, nor their products contribute to the cytotoxicity detected by the assay. The degree of enhancement of specific lysis, approximately 2 -fold, was proportional to the enrichment of $\mathrm{T}$ lymphocytes, again suggesting that these cells are responsible for the lysis. The results using YAC-1 cells as an alternative target suggest that natural killer cells were also enriched by the passage through the nylon wool. However, the cytotoxicity against the YAC-1 cells increased in the enriched splenocytes from both the control and MSZ mice, whereas the cytotoxicity against the RIN cells by the splenocytes from the control mice was unaltered, remaining insignificantly different from basal. These data suggest that the natural killer cell activity is not responsible for the cytotoxicity of the MSZ splenocytes against the RIN cells.

Since the RIN cells are xenogeneic to the mouse effector cells, the lack of MHC restriction poses a problem in the interpretation of these in vitro data. The continued use of the in vivo models takes advantage of the endogenous B cells as the primary targets. After immunization with RIN cells, only the two strains of mice susceptible to MSZ demonstrated a cytotoxic response against the RIN cells in vitro. These strains also exhibited a small, but significant, cytotoxicity against rat lymphocytes after immunization with the RIN cells, but the degree of cytotoxicity against the lymphoblasts was much below that against the RIN cells. These data suggest that the ability to elicit the auto-immune component of MSZ diabetes may be the critical difference between susceptible and non-susceptible strains. The more rapid and severe development of diabetes in susceptible mice immunized with RIN cells, and particularly with hapten-labelled syngeneic islets, is strong though still indirect evidence that a cellular, anti-B cell immune response is necessary for the pathogenesis of MSZ diabetes. The more rapid onset of hyperglycaemia in these immunized mice after MSZ supports the hypothesis that an auto-immune response is activated by the injections of SZ. Moreover, these experiments confirm that the cytotoxic response against the xenogeneic RIN cells in vitro correlates with pathologically significant phenomena in vivo. These experiments also point out, however, the obligate requirement for the Bcell damage by SZ. Thus, the cell-mediated anti-B cell immune response is necessary, but not sufficient, to produce diabetes in these mice.

Interpretation of the results from mice immunized with syngeneic islets is limited by the enhancement of MSZ diabetes by pre-treatment of the mice with adjuvant alone. Other investigators have demonstrated that rats develop diabetes after a MSZ-like protocol only if pre-treated with adjuvant [41]. Once again these data are consistent with the hypothesis of a significant autoimmune component to MSZ diabetes.

Our use of an MHC-non-restricted B-cell target in the cytotoxicity assay makes rigorous evaluation of these phenomena difficult, and we cannot provide any definitive answers at this time. Although syngeneic islets can be isolated and a suspension of islet cells produced by enzymatic digestion, in our hands the viability of these cells is low; the spontaneous release of ${ }^{51} \mathrm{Cr}$ from these cells always exceeds $50 \%$. Even an overnight period in tissue culture was not sufficient to pre- 
vent this high spontaneous release, and thus, for technical reasons, syngeneic islet cells are unacceptable targets in the cytotoxicity assay. While the RIN cells are not an MHC restricted target, the anti-B cell cytotoxicity as measured by the ${ }^{51} \mathrm{Cr}$ release assay was greater in the MSZ mice previously immunized with RIN cells than in either the immunized-only or MSZonly control groups. We interpret these data to indicate that (1) the cytotoxicity as measured by our assay in vitro correlates with the pathologically relevant events (increase in plasma glucose) in vivo, (2) stimulation of an immune response against $B$ cell-related antigens is not by itself sufficient to produce hyperglycaemia, but that such stimulation potentiates the destructive effects of MSZ (i.e. potentiates the immune-related component of the B-cell destruction after MSZ), and (3) the increased plasma glucose, and particularly the increased cytotoxicity in the immunized MSZ mice, suggest that the damage of the mouse B cells by MSZ provokes an immune response against the same or similar antigen(s) to those present on the RIN cells.

One possible mechanism by which SZ could stimulate such an auto-immune reaction is by inducing the expression of either Class I or Class II MHC antigens on the B-cell plasma membrane. Bottazzo et al. [42] have recently demonstrated the presence of DR (Class II) antigens on the B cells in a case of human diabetes, and others have reported the presence of rat Class II MHC antigens on the B cells of BB rats, but only after insulitis had been present for some time [43]. Other investigators have found MHC Class II antigens on normal rat B cells [44]. These investigators did note an increase in such antigens under conditions such as pregnancy that stress the insulin-producing capacity; perhaps this is also the case after MSZ. Recently, gamma interferon has been shown to induce MHC Class I $(\mathrm{H}-2)$ antigens on mouse B cells in vitro [45]. Although it was somewhat surprising that B cells did not normally express these antigens, there was a clearly documented increase in $\mathrm{H}-2$ antigens detectable by immunofluorescence after exposure to gamma interferon. Since lymphokines have been demonstrated to induce the expression of MHC antigens on other cell types, these data provide additional evidence to support an immune component to diabetes.

In summary, these data provide additional support for the hypothesis that hyperglycaemia in mice after multiple subdiabetogenic doses of SZ results, at least in part, from the activation of an auto-immune response against the pancreatic B cells. Further studies, using both in vivo and in vitro techniques, will be needed to identify the specific effector cell(s) responsible for the cytotoxicity against the B-cell targets in vitro and for the production of diabetes in vivo.

Acknowledgements. These studies were supported by research grants from the National Institutes of Health (AM-29921, AM-19631), the Swedish Medical Research Council (12X-109), the American Diabe- tes Association, the Diabetes Research and Education Foundation, the Nordic Insulin Fund, the Juvenile Diabetes Unit of Mount Sinai Hospital, the Swedish Diabetes Association, the Ernfors Foundation for Diabetes Research, a Research Career Development Award (RCM, HD-00285) and a Sinsheimer Fellowship (TMM).

\section{References}

1. Like AA, Rossini AA (1976) Streptozotocin-induced pancreatic insulitis. A new model of diabetes mellitus. Science 193: 415-417

2. Rossini AA, Like AA, Appel MC, Chick WL, Cahill GF Jr (1977) Studies of streptozotocin-induced insulitis and diabetes. Proc Nat Acad Sci (USA) 74: 2485-2489

3. Rossini AA, Williams RM, Appel MC, Like AA (1978) Complete protection from streptozotocin-induced diabetes in mice. Nature 276: 182-184

4. Buschard K, Rygaard J (1978) T-lymphocytes transfer streptozotocin-induced diabetes mellitus in mice. Acta Pathol Microbiol Scand [C] 86: 277-282

5. Beattie G, Lannum R, Lipstick J, Kaplan NO, Osler AG (1980) Streptozotocin-induced diabetes in athymic and conventional BALB/c mice. Diabetes 29: 146-150

6. Nakamura M, Nagafuchi S, Yamaguchi K, Takaki R (1984) The role of thymic immunity and insulitis in the development of streptozotocin-induced diabetes in mice. Diabetes 33: 894-900

7. Paik S-G, Blue ML, Fleischer N, Shen SI (1982) Diabetes susceptibility of BALB/cBOM mice treated with streptozotocin: inhibition by lethal irradiation and restoration by splenec lymphocytes. Diabetes 31: 808-815

8. Hahn HJ, Barnstorf K, Nadrowitz R, Besch W, Schmidt W (1982) The effect of radioimmunosuppression on the development of low dose streptozotocin diabetes. Acta Biol Med Ger 41: 1191-1197

9. Nedergaard M, Egeberg J, Kromann H (1983) Irradiation protects against pancreatic islet degeneration and hyperglycemia following streptozotocin treatment of mice. Diabetologia 24: 82-86

10. Blue ML, Shin S-I (1984) Diabetes induced by subdiabetogenic doses of streptozotocin in BALB/cBOM mice: Noninvolvement of host B lymphocyte function. Diabetes 33: 105-113

11. Kolb H, Kiesel U (1981) Localization of genes controlling an experimental model of human IDDM within and without of the major histocompatibility complex. Immunobiology 160: 58-62

12. Kiesel U, Kolb H (1982) Low-dose, streptozotocin-induced diabetes is under the genetic control of the major histocompatibility complex in mice. Diabetologia 23: 69-71

13. Kiesel U, Falkenberg FW, Kolb H (1983) Genetic control of lowdose streptozotocin-induced autoimmune diabetes in mice. J Immunol 130: 1719-1722

14. Wolf J, Lilly F, Shin S-I (1984) The influence of genetic background on the susceptibility of inbred mice to streptozotocin-induced diabetes. Diabetes 33: 567-571

15. Leiter EH (1984) Genetic control of pathogenesis of diabetes in $\mathrm{C} 3 \mathrm{H}$ mice: Influence of the major histocompatibility complex. Diabetes 33: 1068-1072

16. Kim YT, Steinberg C (1984) Immunological studies on the induction of diabetes in experimental mice. Diabetes 33: 771-777

17. Koevary S, Rossini AA, Stoller W, Chick W, Williams RM (1983) Passive transfer of diabetes in the BB rat. Science 220: 727-729

18. Laupacis A, Gardell C, Dupre J, Stiller CR, Keown P, Wallace AC, Thibert $P$ (1983) Cyclosporin prevents diabetes in BB Wistar rats. Lancet $1: 10-12$

19. Like AA, Dirodi V, Thomas S, Guberski DL, Rossini AA (1984) Prevention of diabetes mellitus in the $\mathrm{BB} / \mathrm{W}$ rat with Cyclosporin A. Am J Pathol 117: 92-97

20. Sestier C, Odent-Pogu S, Bonneville M, Maurel C, Lang F, Sai P (1985) Cyclosporin enhances diabetes induced by low dose streptozotocin treatment in mice. Immunol Lett 10: 57-60 
21. Andersson A, Borg H, Hallberg A, Hellerström C, Sandler S, Schnell A (1984) Direct toxicity of Cyclosporin on beta cells in tissue culture. Diabetologia 27:66-69

22. Bonnevie-Neilsen V, Steffes MW, Lernmark A (1981) A major loss in islet cell mass and $\mathrm{B}$ cell function precedes hyperglycemia in mice given multiple low doses of streptozotocin. Diabetes 30 : 424-429

23. Cossel L, Schneider E, Kuttler B, Schmidt S, Wohlrab F, Schade J, Bochmann Ch (1985) Low dose streptozotocin-induced diabetes in mice. Metabolic, light microscopic, histochemical, immunofluorescence microscopic, electron microscopic and morphometric findings. Exp Clin Endocrinol 85: 7-26

24. Schein PS, Loftus S (1968) Streptozotocin: depression of mouse liver pyridine nucleotides. Cancer Res 28: 1501-1506

25. Robbins MJ, Sharp RA, Slonim AE, Burr IM (1980) Protection against streptozotocin-induced diabetes by superoxide dismutase. Diabetologia 18: 55-58

26. Sandler S, Andersson A (1985) Modulation of streptozotocin-induced insulitis and hyperglycemia in the mouse. Acta Pathol Microbiol Immunol Scand (A) 93:93-98

27. Gold G, Manning M, Heldt A, Nowlain R, Pettit JR, Grodsky GM (1981) Diabetes induced by multiple subdiabetogenic doses of streptozotocin. Lack of protection by exogenous superoxide dismutase. Diabetes 30:634-638

28. McEvoy RC, Andersson J, Sandler S, Hellerström C (1984) Multiple, lowdose streptozotocin-induced diabetes in the mouse. Evidence for stimulation of a cytotoxic, cellular immune response against an insulin-producing beta cell line. J Clin Invest 74: $715-722$

29. McKay P, Boulton A, Rabinovitch A (1985) Lymphoid cells of $\mathrm{BB} / \mathrm{W}$ rats are cytotoxic to islet beta cells in vitro. Diabetes 34 : 706-709

30. McDevitt HO (1982) Regulation of the immune response by the major histocompatibility system. N Engl J Med 303: 1514-1517

31. Marrack P, Kappler I (1986) The T cell and its receptor. Sci Am 254: $36-45$

32. McEvoy RC, Franklin BH, Ginsberg-Fellner F (1986) Biological differences in a rat insulinoma cell line obtained from different laboratories do not affect binding of human anti-islet immunoglobulins. Diabetes Res 3: 339-344

33. Gazdar AF, Chick WL, Oie HK, Sims HL, King DL, Weir GC, Lauris V (1980) Continuous, clonal insulin- and somatostatinsecreting cell line established from a transplantable rat islet cell tumor. Proc Nat Acad Sci (USA) 77: 3319-3323

34. Bloom BR, David JR (1973) A rapid method for the isolation of functional thymus-derived murine lymphocytes. Eur J Immunol 3: $645-649$

35. Lacy PE, Kostianovsky M (1967) Method for the isolation of intact islets of Langerhans from rat pancreas. Diabetes $16: 35-39$
36. Rollinghoff M, Starzinski-Powitz A, Pfizenmaier K, Wagner H (1977) Cyclophosphamide-sensitive T-lymphocytes suppress the in vivo generation of antigen-specific cytotoxic T-lymphocytes. $J$ Exp Med 145: 455-459

37. Sandler S, Andersson A (1981) Islet implantation into diabetic mice with pancreatic insulitis. Acta Pathol Microbiol Immunol Scand [A] 89: 107-112

38. Raabo E, Terkildsen TC (1960) On the enzymatic determination of blood glucose. Scand J Clin Lab Invest 12: 402-404

39. Kiesel U, Kolb H (1983) Suppressive effect of antibodies to immune response gene products on the development of low dose streptozotocin induced diabetes. Diabetes 32: 869-871

40. Mandrup-Poulsen T, Bendtzen K, Nerup J, Dinarello CA, Svenson M, Nielsen JH (1986) Affinity-purified human Interleukin-I is cytotoxic to isolated islets of Langerhans. Diabetologia 29: 63-67

41. Ziegler M, Ziegler B, Hehme B, Deitz H, Hildmann W, Kauert C (1984) Autoimmune destruction of pancreatic beta cells in rats induced by combination treatment with a low dose of streptozotocin and complete Freund's adjuvant. Biomed Biochim Acta 43: 675-681

42. Bottazzo GF, Dean BM, McNally JM, MacKay EH, Swift PGF, Gamble DR (1985) In situ characterization of autoimmune phenomena and expression of HLA molecules in the pancreas in diabetic insulitis. $\mathbf{N}$ Engl $\mathbf{J}$ Med 313: 353-359

43. Dean BM, Walker R, Bone AJ, Baird JD, Cooke A (1985) Prediabetes in the spontaneously diabetic BB/E rat: lymphocytes subpopulations in the pancreatic infiltrate and expression of rat MHC class II molecules in the endocrine cells. Diabetologia 28: 464-466

44. Ulrichs K, Müller-Ruchholtz W (1985) MHC Class II antigen expression on various cells of normal and activated pancreatic islets. Diag Immunol 3: 47-55

45. Campbell IL, Wong GHW, Schrader JW, Harrison LC (1985) Interferon-gamma enhances the expression of the major histocompatibility Class I antigens on mouse pancreatic beta cells. Diabetes 34: 1205-1209

Received: 22 July 1986

and in revised form: 19 February 1987

Dr. Robert C. McEvoy

Departments of Pediatrics and Anatomy

Mount Sinai School of Medicine

One Gustave L. Levy Place

New York, NY 10029

USA 